\title{
The World Health Organization and Immunology Research and Training, 1961-1974
}

\author{
RICHARD HANKINS*
}

\begin{abstract}
Introduction
The history of immunology has attracted the attention of a number of historians in recent years. ${ }^{1}$ The results of their researches have yielded a wealth of insights into technical and disciplinary developments. These works have concentrated, however, on the elucidation of the immune mechanism, studies of autoimmunity and work on viral and bacterial diseases. The notable absence from this historiography is the immunology of the protozoan and metazoan parasitic infections that, whilst major sources of suffering and mortality, have often been marginalized into the concerns of tropical medicine and public health. Issues of parasitism, however, mark one of the closest loci for the interaction of medical and veterinary concerns. Many parasites of man such as Taenia saginata and Trichinella spiralis are believed to be contracted from common farm animals and their meat products. The history of science within the veterinary tradition is little known. Further, the relations between medical and veterinary knowledge in the late twentieth century remain to be elucidated: Protozeăh diseases are also commonly found in other animal populations. For example, bird malaria has been used as a research model since the $1890 \mathrm{~s}^{2}$ One of the first demonstrations of arthropod transmission of pathogenic protozoa was that of Babesia bigemina by the cattle tick, Boophilus annulatus. ${ }^{3}$ An historical approach to the study of this subject can be used to elucidate interactions between issues of human and animal health. Further, the history of parasite immunology provides a useful insight into the relations between twentieth-century medical science and many of the most pernicious diseases of the third world.
\end{abstract}

\footnotetext{
* Richard Hankins, PhD, 13 South Meade, Timperley, Altrincham, Cheshire, WA15 6QL.

The research for this paper was conducted whilst I was a research student at the Wellcome Unit for the History of Medicine, Manchester, and was generously funded by the Wellcome Trust. Mark Jackson's supervision was poignant, plentiful and productive. Many of the staff of the Unit guided me: John Pickstone, Jonathan Harwood and Lyn Schumacker deserve a special mention. Beyond Manchester, Helen Power and Lise Wilkinson have been generous with their time. The weaknesses within this work are, of course, all mine. With thanks to all the fine minds who have taught me over the last decade, and to my family and friends for their unstinting support.
}

\footnotetext{
${ }^{1}$ For example, Pauline M H Mazumdar, Species and specificity: a perspective on the history of immunology, Cambridge University Press, 1995. A M Moulin, Le dernier langage de la médecine: histoire de l'immunologie de Pasteur au Sida, Paris, Presses Universitaires de France, 1991. Arthur M Silverstein, A history of immunology, London, Academic Press, 1989.

${ }^{2}$ P C C Garnham, 'History of discoveries of malaria parasites and of their life cycles', Hist. Phil. Life Sci., 1988, 10: 93-108.

${ }^{3}$ Edward A Steinhaus, Insect microbiology, New York, Hafner Publishing Company, 1967, pp. 3-4.
} 


\section{Richard Hankins}

The absence of parasite immunology in the historiography of medicine reflects a similar absence in the practice of science. Whilst immunological approaches to the study of viral and bacterial disease have been popular throughout the twentieth century, this has not been reflected in work on metazoan and protozoan infections. The eventual development of parasite immunology as an area of study occurred through varying disciplinary associations in different regions. For example, in the UK, parasite immunology developed through an affiliation with malaria therapy, tropical medicine, veterinary research, immunology and parasitology. ${ }^{4}$ The limited influence of tropical medicine in the post-war period, and its concentration within two relatively small institutions in London and Liverpool, ensured that even strong links to this discipline offered only restricted opportunity for the development of the field. Whilst links to veterinary research can be shown to have been important, veterinary research in the UK has remained remarkably limited.

The development of parasite immunology in the United States was the product of considerably different economic considerations and disciplinary relations. In the UK domestic malaria has caused little concern in the twentieth century except during the two World Wars, ${ }^{5}$ and nematode infections have been only marginal concerns. Conversely, in the USA, the existence in some states of hyperendemic hookworm as well as endemic malaria, coupled with military concerns regarding parasitic disease in South America, facilitated the development of parasite immunology in association with public health as well as tropical medicine. In inter-war America, the philanthropic activities of the Rockefeller Foundation facilitated the development of an extensive parasite immunology network. ${ }^{6}$ Not only was a great deal of research funded by the Foundation but many of the earliest parasite immunologists were trained at the Johns Hopkins University School of Hygiene and Public Health. Opened in 1916 with Rockefeller Foundation sponsorship, this school was one of "the principal centres for the Rockefeller Foundation's International Health Board's campaign for world-wide improvements in public health through applied medical science and education". ${ }^{7}$ As Ilana Löwy has noted, the school functioned essentially as a training institution for Rockefeller personnel. ${ }^{8}$ As a product of its agenda to apply the most advanced science to issues of public health, the Foundation provided opportunities for initial training in parasite immunology and a subsequent career structure.

Despite these developments in the UK and USA, in 1964 a World Health Organization expert Committee on Immunology and Parasitic Diseases concluded in its report that research activities relating to the immunology of parasitic diseases

\footnotetext{
${ }^{4}$ For an extended discussion of the development of parasite immunology, see Richard Hankins, 'Between tropical disease and veterinary medicine: the development of immunological studies of parasitism', PhD thesis, University of Manchester, 1998.

${ }^{5}$ Leonard Jan Bruce-Chwatt and Julian de Zulueta, The rise and fall of malaria in Europe: $a$ historico-epidemiological study, Oxford University Press, 1980.
}

\footnotetext{
${ }^{6}$ Hankins, op. cit., note 4 above, pp. 81-172.

${ }^{7}$ Lise Wilkinson, Animals and disease, Cambridge University Press, 1992.

${ }^{8}$ Ilana Löwy, 'Controlling viruses, antibodies and humans: the development of anti-yellow fever vaccine, 1928-1943', presented at Wellcome Unit for the History of Medicine, Manchester, 17 March 1998.
} 
were extremely limited. Contemporary immunologists, it would seem, had little insight into the problems faced by parasitologists. ${ }^{9}$

In subsequent years, the WHO launched an international scheme of Immunology Research and Training Centres (WHO IRTCs). In this paper I will show that these IRTCs represented a deliberate attempt to redefine the discipline of immunology thus incorporating WHO concerns regarding infectious diseases of parasitic etiology. The Centres were mostly located within "tropical" countries and were thus brought into proximity with indigenous parasitic diseases. However, the placing of centres was not based on a formal policy. Instead, the WHO looked for pre-existing facilities combined with an enthusiastic immunologist or sympathetic administration. Thus, as well as the politically attractive centres in Africa, Asia etc., the WHO found it convenient to found centres in Europe and Australasia. As a result of varying funding arrangements, WHO control of the centres was far from total. Despite this, Geneva-based WHO staff were active in influencing the research activities of the three Centres studied here. It can be seen that the WHO IRTCs at Ibadan, São Paulo and Lausanne functioned as research and training centres in parasite immunology.

\section{WHO Research}

Involvement in research was incorporated within the WHO's constitution. Under this remit the new Organization was to "promote and conduct research in the field of health" ${ }^{10}$ Despite this obvious constitutional mandate, research was not considered to be a major responsibility of the Organization. ${ }^{11}$ Its initial focus had been on often large-scale field work projects, most notably the malaria eradication scheme. By 1960 the annual malaria account of the WHO exceeded the regular budget by almost US $\$ 2$ million. ${ }^{12}$ Even with such massive investment, the restricted success of the malaria programme must have highlighted the limitations in contemporary technology and knowledge. At the Eleventh World Health Assembly in Minneapolis in June 1958, however, the American delegation offered a special contribution of $\$ 300,000$ to facilitate a study "of the role of WHO in research and the ways in which the Organization might assist more adequately in stimulating and co-ordinating research and developing research personnel" ${ }^{13}$ A subsequent resolution was passed (WHA 11.35) ${ }^{14}$ which accepted the donation and instructed the Director to prepare the suggested report for presentation at the Twelfth World Health Assembly and the twenty-third meeting of the executive board.

\footnotetext{
${ }^{9}$ Immunology and parasitic diseases, WHO

Technical Report Series, No. 315, Geneva, WHO, 1965, pp. 5-6.

${ }^{10}$ The first ten years of the World Health Organization, Geneva, WHO, 1958, p. 460.

${ }_{11}$ 'Twelfth World Health Assembly, Geneva, 12-29 May 1959', Official records of the WHO, No. 95, Geneva, WHO, 1959, p. 505.

${ }^{12}$ Sung Lee, 'WHO and the developing world: the contest for ideology', in Andrew Cunningham
}

and Bridie Andrews (eds), Western medicine as contested knowledge, Manchester University Press, 1997 , pp. 2445 , on p. 29.

${ }^{13}$ The medical research programme of the WHO 1958-1963, Geneva, WHO, 1964, p. 1.

${ }^{14}$ Handbook of resolutions and decisions of the world health assembly and the executive board, 1948-1972, vol. 1, Geneva, WHO, 1973, p. 24. 


\section{Richard Hankins}

At the Twelfth World Health Assembly in Geneva in 1959, the Director General provided an account of the history of WHO medical research:

Research is a part of the constitutional mandate of WHO, but relatively little emphasis was put on this function at the outset. The core of the Organization's early programmes consisted of certain central functions of public health importance and direct assistance to governments in the control of particular mass diseases, mostly communicable. Nevertheless, as early as the Second World Health Assembly the principles that should govern future WHO research activities were considered, because it was realized that the scientific knowledge available was not adequate to secure the success of the disease control programmes ... Thus, in the course of the years, the Organization gradually developed some research activities, particularly in the field of communicable diseases. ${ }^{15}$

When contrasted with this utilitarian tradition, the research programme set out in the American-funded report marked a significant change. Central to this transition was the demolition of boundaries between "fundamental" and "applied" research, with such categories condemned as "artificial". ${ }^{16}$ This reconceptualization of all research work as part of "a continuous spectrum" allowed for a massive increase in the research remit of the Organization: in the future almost all medical science was to be considered a valid activity for WHO involvement. The objectives of the WHO Intensified Medical Research Programme were the stimulation and initiation of new research, as well as the promotion, organization and co-ordination of existing research. ${ }^{17}$ In particular, the programme was to support the expansion of work in "special world health problems", whilst "advancing medical research generally". 18

While the philosophy of the new project outlined in the Director-General's report clearly provided for a near universal research agenda, a number of specific research areas were given high priority in the initial year. The communicable diseases were acknowledged as being the "greatest hazard to the health of man". ${ }^{19}$ These infectious diseases were central to the culture of the Organization and had formed the core of WHO interests since its founding. Conversely, it was recognized that in many of the developed countries the "chronic" (non-infectious) conditions were "of prime importance".$^{20}$ It was initially estimated that the cost of the programme would be as high as $\$ 2,200,000$ for the first year alone. ${ }^{21}$ To facilitate such great expenditure an account was opened for the receipt of voluntary donations. ${ }^{22}$

Consequently, from around 1960, the medical research programme of the WHO was intensified. As the WHO's funds were relatively limited, the Organization attempted to stimulate and control research through the provision of training and equipment rather than simply funding limited research projects. Whilst the research programme was broad, the WHO tradition of work on communicable diseases continued to dominate, with this area initially accounting for over 50 per cent of the expenditure. ${ }^{23}$ Of the communicable diseases included, those of viral etiology

${ }^{15}$ Official Records of the World Health

Organization, No. 95, Geneva, WHO, 1959, p. 27.

${ }^{16}$ Ibid., p. 505 .

${ }^{17}$ Ibid., p. 506.

${ }^{18}$ Ibid., p. 506.

${ }^{19}$ Ibid., p. 618.

${ }^{20}$ Ibid., p. 518 .
${ }^{21}$ Ibid., p. 518.

${ }^{22}$ See Resolution WHA 12.17 parts 8 and 9 in WHO, Handbook of resolutions and decisions of the World Health Assembly and Executive Board 1948-1972, vol. 1, Geneva, WHO, 1973, p. 25.

${ }^{23}$ Official records of the World Health Organization, No. 131, Geneva, WHO, 1964, p. 6. 
received the greatest research funding, but the parasitic diseases received between US $\$ 200,000$ and $\$ 300,000$ per annum between 1961 and 1963 . They were, therefore, a significant part of the new programme. ${ }^{24}$

\section{The World Health Organization Immunology Research and Training Centres}

The WHO's involvement in disciplinary immunology was initiated by a series of five meetings of "experts". Held in Geneva between 22 January and 9 June 1962, these meetings consisted of the Scientific Groups on Immunoprophylaxis and Immunotherapy; Immunopathology; Immunochemistry; Tissue Antigens and Transplantation; and the Research Programme in Immunology. The deliberations of these five meetings were published as a technical report under the title Research in Immunology, ${ }^{25}$ which, it was claimed, provided a "presentation of the key problems in immunology". ${ }^{26}$ These meetings were essentially a consultation exercise designed to outline appropriate research areas for WHO intervention. Such interest was based not only on a belief that "immunology [was] one of the fastest growing fields of medicine" but also the notion that "its ramifications are extending into many other fields, revivifying research in a host of subjects" ${ }^{27}$ As such, immunology was to be of "central importance" 28 to the Organization's medical research programme. The report of the Scientific Group on Immunoprophylaxis and Immunotherapy acknowledged the contemporary importance of the development of "Dictol", an irradiated vaccine against the nematode pathogen Dictyocaulus viviparus, and subsequent research on anti-parasitic vaccines at the Glasgow Veterinary School. ${ }^{29}$

While the first four of these meetings outlined the contemporary issues in immunology research, the fifth on the "Research Programme in Immunology" set out largely to provide a research agenda. Surprisingly, the recommendations of the meeting did not concentrate primarily on specific technical problems appropriate for WHO involvement. Instead, the delegates elaborated upon a training and service role which the WHO might profitably fulfil:

Highest priority should be given to the setting up of long-range education and training programmes in Africa, Asia and South America. These should involve the establishment of functioning units in immunology on a long term basis (at least five years). Arrangements should be made for a senior person to spend three months a year for several successive years in a university or medical school in an area selected for this programme, to conduct courses, carry out research, and train collaborators from the area. During the three-month period plans for continued activity for the rest of the year could be made and carried out by the other workers, supplemented, if possible, by a suitably qualified junior assistant who would

\footnotetext{
${ }^{24}$ The expenditure on the parasitic diseases quoted is calculated by adding the amount spent on "parasitic diseases" to the amount spent on malaria. See WHO, op. cit., note 11 above, pp. 9-11.

${ }_{25}$ Research in immunology, WHO Technical Report Series, No. 286, Geneva, WHO, 1964.
}

\footnotetext{
${ }^{26}$ Ibid., p. 4.

${ }^{27}$ Ibid., p. 4.

${ }^{28}$ Ibid., p. 4.

${ }^{29}$ Ibid., pp. 9-10.
} 


\section{Richard Hankins}

come for a longer period. Many of the problems of the developing countries can best be solved by groups working on the spot. ${ }^{30}$

The slightly patronizing nature of these proposals-note the developing countries were not considered able to provide even a junior assistant-was possibly a product of the Western dominance of the committee. ${ }^{31}$ Immunology, perceived as a modern, highly technical Western construct, would be transferred to Africa, Asia and South America by the movement of Western personnel.

The service functions proposed in the report ${ }^{32}$ of the Scientific Group included the provision of an information facility listing the availability of reagents and experimental animals. Also the Organization's leading role in the standardization of nomenclature and serological methodology was outlined. Finally, reference centres should be founded "for the examination, storage, exchange, and distribution of sera from patients with auto-allergic diseases, specific plasma protein deficiencies and sensitivities to drugs and other substances". ${ }^{33}$ The committee concluded with a list of only seven research activities in which the WHO might fruitfully be involved. These suggestions varied from the provision of assistance in field trials of vaccines to surveys of human immunoglobulin levels, with an emphasis on the study of autoimmune conditions. The role proposed for the Organization in the study of the immunology of communicable diseases was to be parasitological research:

Investigations should be made into the antigenic composition of protozoa and helminths and the immunological mechanisms involved in resistance to or recovery from infection by these agents. Such investigations are potentially fruitful both for epidemiological studies and for the development of practical immunization procedures. ${ }^{34}$

As a result of this recommendation, a WHO expert committee on "Immunology and Parasitic Diseases" was convened at Ibadan in $1964 .{ }^{35}$ The committee consisted of such eminent immunologists as $\mathrm{J}$ H Humphrey and I Riha, as well as notable parasitologists such as E J L Soulsby and W P Rogers. The outstanding position of the Glasgow Veterinary School, whose researchers had recently developed a commercially successful irradiated vaccine to lungworm in cattle, was acknowledged by the membership on this committee of I McIntyre, Professor of Veterinary Medicine at Glasgow. ${ }^{36}$

\footnotetext{
${ }^{30}$ Ibid., p. 79.

${ }^{31}$ The Scientific Group on the Research Programme in Immunology consisted of Sir Macfarlane Burnet (Australia), Dr A H Coons (USA), Dr J H S Gear (South Africa) and Dr P Grabar (France).

${ }^{32}$ For full details of the proposals, see Research in immunology, op. cit., note 25 above, pp. 80-1.

${ }^{33}$ Ibid., p. 81.

${ }^{34}$ Ibid., p. 83.

${ }^{35}$ The proceedings of this meeting were published as Immunology and parasitic diseases, WHO Technical Report Series, No. 315, Geneva, WHO, 1965.
}

\footnotetext{
${ }^{36}$ Members of the committee: D A L Davies (Medical Research, Victoria Hospital, Sussex), F J Dixon (Experimental Pathology, Scripps Clinic, USA), J C Edozien (Medical School, University of Ibadan, Nigeria), J H Humphrey (Immunology, NIMR, UK), I McIntyre (Veterinary Medicine, Glasgow, UK), I Riha (Microbiology, Czechoslovak Academy of Science, Czechoslovakia), W P Rogers (Zoology, University of Adelaide, Australia), E J L Soulsby (Parasitology, Veterinary Medicine, University of Pennsylvania, Philadelphia).
} 


\section{The WHO and Immunology Research and Training, 1961-1974}

The committee lamented the limitations of the contemporary parasite immunology tradition:

The close contact between immunology and bacteriology since the beginning of the century has not been paralleled by similarly close contact between immunology and parasitology . . . It is hoped that the report, even though it discloses the wide gaps in present knowledge of the immunology of certain parasitic diseases, will nevertheless serve to provide immunologists with an outline of some of the problems with which parasitologists are faced, and induce more parasitologists to consider the possibility of a fruitful approach to these problems in terms of immunological concepts. ${ }^{37}$

Subsequently, the report consisted largely of a review of the current status of parasite immunology. The final section recommended important research and anticipated the role that the WHO Immunology Research and Training Centres were to play in the promotion of parasite immunology:

The committee gave high priority to the programme for WHO Immunology Training and Research Units in developing countries, one example being the newly organized prototype unit at the University of Ibadan, Nigeria. The programme is based on providing training in research and by bringing scientists to the developing countries, in order to avoid the ill-effects due to geographical dislocation of the scientist in training, which too often include failure to return to his native country.

The programme of training is designed to give broad modern theoretical and experimental knowledge of research trends and techniques, with a view to stimulating creativity and a level of technical skill suitable for the most advanced attack on fundamental and practical problems of medicine and allied sciences.

In addition, the eminent scientists who will undertake the training and research will be brought at the same time into direct contact with the pressing health problems of the developing countries, inter alia the parasitic diseases. This can be expected to increase the number of immunologists who will take up problems directly or indirectly related to the parasitic diseases. ${ }^{38}$

From the earliest founding of the Centres, therefore, it was implied that the WHO Immunology Research and Training Centres were to have a role not only in the promotion of immunology but also in the defining of immunology's disciplinary boundaries. The marginalization of parasitic disease research into the limited speciality of tropical medicine (especially in Europe), with its attendant epidemiological and entomological traditions and limited research base, had located parasite immunology within a disciplinary vacuum. The founding of WHO IRTCs was a conscious attempt to redress an absence in both the parasitology and immunology traditions.

\section{WHO IRTC, Ibadan, Nigeria}

The early records of the World Health Organization Immunology Research and Training Centre, at the University of Ibadan $^{39}$ have not been available. The official

\footnotetext{
${ }^{37}$ Immunology and parasitic diseases, op. cit., note 35 above, pp. 5-6.

${ }^{38}$ Ibid., p. 64.

${ }^{39}$ For further details of the progressive nature of the University of Ibadan see, Helen
}

Power, Tropical medicine in the twentieth century: a history of the Liverpool School of Tropical Medicine 1898-1980, London, Kegan Paul, 1999. 


\section{Richard Hankins}

agreement between the WHO and the University which provided for the formalization of the funding and administration of the Centre was not signed until the autumn of $1966 .^{40}$ However, there is some evidence that activities in Ibadan pre-dated the official agreement, as Dr I Riha of the Czechoslovakian Academy of Science appears to have delivered a course there in $1965 .{ }^{41}$ The objectives of this unit as formally agreed between the WHO and the University were twofold. It was to provide a four to six month course for African postgraduate students and also carry out a research programme as agreed by the Department of Chemical Pathology, University of Ibadan, and the World Health Organization. ${ }^{42}$

Attracting eminent Western scientists to Africa in the 1960s was predictably difficult. In particular, the social and political instabilities of Nigeria made the country especially unattractive. With the conclusion of Dr Riha's brief consultancy in 1965 the Centre was left without a senior scientist. The only trained Western member of staff was Ada E Bezer, an American laboratory technician. Despite these unfortunate circumstances, Bezer found herself able to teach laboratory methods, and give a few basic lectures to Gabriel Otiko, her African counterpart, as well as a number of undergraduates. ${ }^{43}$ Research at the Centre continued despite the absence of a research scientist. By November 1967, Bezer had begun a project to prepare specific antiserum to African IgM under David Rowe of the University of Lausanne. Gabriel Otiko was continuing his training in basic immunological techniques whilst also beginning research on antibody production to foetal protein under Hylton McFarlane of Ibadan University's Department of Chemical Pathology. ${ }^{44}$

It was some three years before a temporary solution to the staffing crisis was found. In January 1968 Dr Vashek Houba, ${ }^{45}$ an immunologist and rheumatologist, arrived on temporary secondment from the Czechoslovakian Academy of Science. Whilst in Ibadan, Houba was to take on the role of WHO consultant in immunology and Temporary Director of the Centre. ${ }^{46}$ With his arrival, the research profile of the Centre was to change. Houba was not, however, the instigator of this change. As early as 1966, M W Turner of Great Ormond Street Hospital, London, had visited the Centre in the capacity of Temporary Adviser to the WHO. ${ }^{47}$ Turner was asked to "investigate the technical arrangements necessary for the further investigation of the postulated role of antigen excess soluble complex in the Plasmodium malariae nephrotic syndrome". ${ }^{48}$ Upon his return to the UK, Turner had begun a collaborative project on this subject with R G Hendrickse, then Professor of Paediatrics at the

\footnotetext{
${ }^{40}$ World Health Organization Archive, Geneva, (hereafter WHO Archive), 'Agreement between the University of Ibadan, Ibadan, Nigeria and WHO on the establishment of a WHO Immunology Research and Training Centre, September and October 1966', WHO I5/ 286/4(A).

${ }^{41}$ WHO Archive, 'Immunology course programme', accredited to Dr I Riha and dated 1965, I5/286/4(A).

${ }^{42}$ WHO Archive, 'Agreement between the University of Ibadan and the WHO', I5/286/4(A).
}

${ }^{43}$ WHO Archive, Letter from A E Bezer to Z Trnka, 13 Nov. 1967, I5/286/4(A) and 'Quarterly field report', 13 Nov. 1967, I5/286/4(A).

${ }^{44}$ WHO Archive, 'Quarterly field report', 13 Nov. 1967, I5/286/4(A).

${ }^{45}$ Houba is occasionally called Vaclav Houba in correspondence.

${ }^{46}$ WHO Archive, 'Quarterly field report', Jan. 1968, I5/286/4(A).

${ }^{47}$ WHO Archive, 'Visit to University College

Hospital, Ibadan', 18-23 Dec. 1966, I5/286/4(A).

${ }^{48}$ Ibid. 
University of Ibadan.$^{49}$ Turner and Hendrickse were joined in this work by Professor John Soothill of Great Ormond Street Hospital, who also visited Ibadan as a Temporary Adviser to the WHO in $1966 .{ }^{50}$ With the arrival of a full-time Director, the staff of the Immunology Section of the WHO were keen to "overcome the service type small project mentality" which the Centre was perceived to have. ${ }^{51}$ It was proposed that a "stable research project" 52 was needed to achieve this, and the immunology of malaria, with its WHO-inspired local tradition, was selected. ${ }^{53}$

Within three months, malarial immunology had begun at the Centre. Houba was collaborating with Professor J B Lawson of the Department of Obstetrics and Gynaecology, University College Hospital, Ibadan, on a project to study levels of immunoglobulins in malarious pregnant women. Other research in the Centre included a study of antibody levels in trypanosomiasis infected cattle in collaboration with the Veterinary Department of the University, and a small amount of work on Houba's long-standing interest in immunoglobulins in meningitis. ${ }^{54}$ By June, the studies of pregnant women had been concluded and, along with Tony Allison of the National Institute of Medical Research, UK, Houba had begun to study the role of immune complexes in malaria nephrotic syndrome in children. Concurrently, studies on trypanosomiasis in cattle continued along with a limited amount of work on meningitis. ${ }^{55}$

With the impending conclusion of Houba's six-month consultancy the future of the Centre and the continuation of its research activities again came under threat. The difficulties of appointing a "Team Leader" to the Ibadan Centre were being discussed between the Assistant-Director General of the WHO and the Organization's immunology section..$^{56}$ The unpopularity of overseas work in the post-war period, coupled with the buoyant market for medical scientists, ensured that appointing a Western scientist of sufficient status to a post in Africa was difficult. Consequently, it was hoped that Houba would apply for the permanent Directorship of the Centre upon the conclusion of his consultancy. ${ }^{57}$ However, within three months of his arrival Houba had expressed his wish to leave Africa ${ }^{58}$ Nigeria was still experiencing the ramifications of civil war and Ibadan was a tense place in which to live. The Houbas' determination to leave Africa had been accentuated by a burglary whilst they were at home, and the theft of the Centre's car. ${ }^{59}$ In an attempt to avert the impending crisis, Hylton McFarlane wrote to Howard Goodman, the Chief of Immunology at the WHO in Geneva. Formerly head of clinical immunology at the National Institute of Allergy and Infectious Disease, USA, Goodman was evangelical about the need

\footnotetext{
${ }^{49}$ WHO Archive, Letter from M W Turner to R G Hendrickse, 30 Dec. 1966, I5/286/4(A).

${ }^{50}$ WHO Archive, Letter from H C Goodman to P M Kaul, 20 Oct. 1966, I5/286/4(A)

${ }^{51}$ WHO Archive, Letter from Z Trnka to H C Goodman, 9 Feb. 1968, I5/286/4(A).

${ }_{52}^{5}$ Ibid.

${ }^{53}$ Zdenek Trnka of the Immunology Division of the WHO suggested the research problems for the Centre should be selected from the recent report of the Scientific Group on the Immunology of Malaria. See WHO Archive,
}

Letter from Z Trnka to H C Goodman, 9 Feb. $1968, \mathrm{I} 5 / 286 / 4$ (A).

${ }^{54}$ WHO Archive, 'Quarterly field report', 9 April 1968, I5/286/4(A)

${ }^{55}$ WHO Archive, 'Quarterly field report', 7 June 1968, I5/286/4(A).

${ }^{56}$ WHO Archive, Internal memo $Z$ Trnka to

A M-M Payne, 24 July 1967, I5/286/4(A).

${ }^{57}$ Ibid.

${ }^{58}$ WHO Archive, Letter from V Houba to $\mathrm{H}$

C Goodman, 23 July 1968, I5/286/4(A).

${ }^{59}$ Ibid. 


\section{Richard Hankins}

for increased research into tropical disease. Subsequently, he was to promote and direct the WHO's much more expansive tropical disease research and training programme. The problem of appointing a Western Director, McFarlane believed, could be circumvented by elevating the Centre to a Department of Immunology, and thus attracting a Nigerian for the post. ${ }^{60}$

Ironically, it was civil and political unrest in Czechoslovakia that afforded a solution. On 3 July 1968, Houba wrote to Goodman stating that his position as a research scientist in Czechoslovakia had become untenable. This situation, he explained, coupled with his satisfaction at the demonstration of immune complexes in the glomeruli of children suffering from malaria nephrotic syndrome, encouraged him to apply for the permanent post of Director. His application was not unconditional: he would accept the post only if he was granted regular study trips to European laboratories as well as home leave. ${ }^{61}$ Within three weeks of this application, news of Houba's appointment, apparently unchallenged, had reached Africa. ${ }^{62}$

The appointment of a permanent Director guaranteed the immediate future of the Centre. With the recommencement of research activities early in 1969, the parasitological focus of the Centre was secured. The early success of research on malarial nephrotic syndrome, coupled with the accessibility of subjects in University College Hospital (UCH), Ibadan, made this an obvious focus for the renewed research effort. ${ }^{63}$ Houba and his collaborators in the Department of Paediatrics, $\mathrm{UCH}$, reviewed the results of the 1968 work and decided to continue the project:

(a) to include new patients into groups under observation;

(b) to repeat the renal biopsies in patients investigated in 1968 (e.g. after treatment) and;

(c) to evaluate the effect of therapy. ${ }^{64}$

Work on malaria nephropathy syndrome continued until the WHO's withdrawal from the Centre, and its Africanization as a department of Ibadan University in the summer of 1972. During the previous years this rich line of research had led to many of the Centre's most prestigious publications in journals such as the Lancet and Clinical and Experimental Immunology. ${ }^{65}$ Other malarial immunology research at the Centre included studies of soluble Plasmodium falciparum serum antigens in collaboration with A I O Williams, a PhD student in the Department of Chemical

\footnotetext{
${ }^{60}$ WHO Archive, Letter from H McFarlane to H C Goodman, 17 June 1968, I5/286/4(A).

${ }^{61}$ WHO Archive, Letter from V Houba to $\mathrm{H}$ C Goodman, 23 July 1968, I5/286/4(A).

${ }^{62}$ WHO Archive, Letter from A E Bezer to $\mathrm{H}$ C Goodman, 13 Aug. 1968, I5/286/4(A)

${ }^{63}$ The earlier portion of this work was published as A C Allison, R G Hendrickse, G M Edington, V Houba, S De Petris and A Adeniyi, 'Immune complexes in the nephrotic syndrome of African children', Lancet, 1969, i: 1232-8.

${ }^{64}$ WHO Archive, 'Quarterly field report', 22 May 1969, I5/286/4(A).
}

\footnotetext{
${ }^{65}$ Allison, et al., op. cit., note 63 above, pp. 1232-8; A Adeniyi, R G Hendrickse and V Houba, 'Selectivity of proteinuria and response to prednisolone or immunosuppressive drugs in children with malarial nephrosis', Lancet, 1970, i: 644-8; V Houba, A C Allison, A Adeniyi and J E Houba, 'Immunoglobulin classes and complement in biopsies of Nigerian children with nephrotic syndrome', Clin. Exp. Immunol., 1971, 9: 761-74; R G Hendrickse, A Adeniyi, G M Edington, E F Glasgow, R H R White and V Houba, 'Quartan malarial nephrotic syndrome: collaborative clinicopathological study in Nigerian children', Lancet, 1972, i: 1143-9.
} 


\section{The WHO and Immunology Research and Training, 1961-1974}

Pathology. ${ }^{66}$ The other consistent research interest in the centre was the study of antibodies in cattle and rabbits suffering from trypanosomiasis. This work was conducted in collaboration with the veterinary department of the University and members of the WHO Trypanosomiasis Project, Kenya ${ }^{67}$ The work of the laboratory was communicated not only through publications, but also through conference presentations given by Houba, ${ }^{68}$ as well as the presence of Houba and associated staff at WHO Scientific Group meetings. ${ }^{69}$

The research activities of the Ibadan Centre appear to have correlated well with the objectives of the WHO Immunology Research and Training Programme. Despite considerable effort and investment, the Centre's teaching programmes achieved only very localized influence. At the initial meeting at which the roles of the IRTCs were defined "prime emphasis" was placed "on the urgency and importance of training immunologists".${ }^{70}$ In subsequent negotiations between the University of Ibadan and the WHO it had been agreed that the main vehicle for this training function would be an annual four to six month course taught by the staff of the Centre, assisted by a number of eminent visiting consultants. ${ }^{71}$ The course consisted largely of lectures combined with practical sessions and practical demonstrations, and provided a broad introduction to the "basic" immunology of the day. The latter stages included a research project and predictably this introduced the students to the parasitological interests of the Centre's staff. Subsequently, a number of participants continued research in parasite immunology upon completion of the course. ${ }^{72}$

At the African Centre, such "annual" courses were offered in 1965, 1968, 1969, 1970 and 1972. Whilst those for 1966 and 1967 had been cancelled due to the staffing crisis outlined earlier, the 1971 course was abandoned because of the growing frustration of the WHO at the failure of this expensive programme to attract students from outside Nigeria. Instead, it was decided that the money for that year could be

\footnotetext{
${ }^{66}$ WHO Archive, 'Quarterly field report', 1 April 1971, I5/286/4(A). This work led to a number of publications: V Houba and A I O Williams 'Soluble serum samples of Plasmodium falciparum in Nigerians. I. Local incidence of malarial soluble serum antigens and antibodies', Afr. J. med. Sci., 1972, 3: 295-307; V Houba and A I O Williams, 'Soluble serum antigens of $P$. falciparum in Nigerians. II. Immunochemical studies', Afr. J. med. Sci., 1972, 3: 309-17.

${ }^{67}$ WHO Archive, 'Quarterly field report', July 1970, I5/286/4(A).

${ }^{68}$ Houba was funded to travel to Britain in 1970 to present a paper titled 'Immunoglobulin classes and complement in serial biopsies of African children with nephrotic syndrome' at a British Society for Immunology meeting in London. Houba presented a further paper at the Second International Congress on Immunology, Brighton, July 1974.

${ }^{69}$ For example, at the Scientific Group on Developments in Malaria Immunology at Geneva
}

23 April to 2 May 1975 Houba was a member of the secretariat B O Osunkoya, Senior Lecturer in immunology in the Department of Chemical Pathology from 1970 and, after Houba's departure, the Director of the re-named WHO Collaborating Centre on Immunology Research and Training, Ibadan, was Vice-Chairman of the Scientific Group.

${ }^{70}$ Research in immunology, op. cit., note 25 above, p. 79 .

${ }^{71}$ Consultants included A Allison, A J S Davies, J Sterlz, J Fahey, G Asherson and J Holborow.

${ }^{72}$ For example, A Williams wrote a $\mathrm{PhD}$ thesis and numerous articles on malarial immunology. Dr Esuroso collaborated on trypanosomiasis work and Drs Abioye and Ademola worked on amoebiasis and big spleen disease. 


\section{Richard Hankins}

better spent by allowing Houba to travel to different African countries "to stimulate interest in immunology and to assess candidates personally". ${ }^{73}$ Other activities in the Centre included the supervision of undergraduate ${ }^{74}$ and postgraduate students. ${ }^{75}$ Professor Houba and Dr Osunkoya (Senior Lecturer in Immunology, Department of Chemical Pathology) ${ }^{76}$ also lectured to medical students ${ }^{77}$ and from 1972 an MMed course was delivered. ${ }^{78}$

The success of the teaching function of the Centre was considered to be limited. The annual course attracted only a handful of applications and these were usually from members of Ibadan University. Despite considerable expenditure on recruitment for the 1972 course only seven students attended, of whom four were Nigerians. ${ }^{79}$ The lack of influence of the teaching programme was a major factor in the decision to transfer the Centre to local control at an early stage. In a 1971 memo titled the 'Future Existence of WHO IRTC, Ibadan', Houba himself admitted that the Centre "had trained a few West Africans from other countries but had achieved nothing for East Africa" ${ }^{80} \mathrm{He}$ concluded this memo by suggesting that the Centre be transferred to the University of Ibadan and the WHO staff moved to Nairobi, Kenya, to found an East African IRTC. The agreement between the WHO and the University of Ibadan was brought to an end in March 1972 with an official explanation in terms of the professionalism of the University's staff:

This letter terminating the agreement with the University reflects our considered opinion that a stage has been reached that the University of Ibadan has a professional immunological staff fully qualified to continue research and training in immunology without the constant assistance of a WHO team. I trust that this procedure will meet with your approval. ${ }^{81}$

Such an explanation is congruent with earlier assertions that the WHO IRTCs would eventually come under local control and persist as departments of immunology. ${ }^{82}$ Consequently, the termination of the agreement appears to have been accepted without objection. The early transfer of the Nigerian Centre was largely instigated by the perceived failure of the intended teaching programme. Subsequently, the laboratory was renamed the WHO Collaborating Centre on Immunology Research and Training, Ibadan, and was directed by B O Osunkoya. Under the new

\footnotetext{
${ }^{73}$ WHO Archive, Letter from H C Goodman to Parker A Small, 1 Sept. 1970, I5/286/4(A).

${ }^{74}$ WHO Archive, 'Quarterly field report', 13 Nov. 1967, I5/286/4(A).

${ }^{75}$ For example, Dr G O Esuruoso, 'Cellular pathology of pathogenic trypanosomes', Dr A A Abioye, 'Immunopathology of amoebiasis in Ibadan' and Dr Sagoe, 'Tropical splenomegaly in Ibadan'.

${ }^{76}$ Dr Osunkoya transferred from the Department of Pathology to the Department of Chemical Pathology to take up the post of Senior Lecturer in Immunology in 1970. WHO Archive, 'Quarterly field report', 14 Jan. 1971, I5/286/4(A)

${ }^{77}$ WHO Archive, 'Quarterly field report', 30 Oct. 1969, I5/286/4(A).
}

${ }^{78}$ WHO Archive, 'Quarterly field report', 28 April 1972, I5/286/4(A).

${ }^{79}$ The seven students consisted of four Nigerians, one Ugandan, one Kenyan and one Tanzanian. WHO Archive, 'Quarterly field report', 28 April 1972, 15/286/4(A).

${ }^{80}$ WHO Archive, Internal memo V Houba to H C Goodman, 'Future existence of WHO IRTC, Ibadan', 18 Dec. 1971, I5/286/4(A).

${ }^{81}$ WHO Archive, Letter from T A Lambo (Acting Director-General, WHO) to G M Edington (Acting Vice-Chancellor, University of Ibadan), 1 March 1972, I5/286/4(A).

${ }^{82}$ H C Goodman, 'WHO: International Research', World Health, June 1972: 20-5, p. 20. 
directorship the malariology tradition of the Centre was continued ${ }^{83}$ As proposed, Houba moved to Nairobi, Kenya, where he founded and directed a new WHO IRTC. ${ }^{84}$ At this location he continued his researches into malarial immunology before expanding into trypanosomal research.

\section{WHO IRTC, São Paulo, Brazil}

Within months of the opening of the Ibadan Centre, negotiations had begun regarding the opening of a similar enterprise in São Paulo. ${ }^{85}$ An established local scientist, Otto Bier, had secured informal agreement for the provision of fellowships from the National Research Council of Brazil, and assurances from universities and research institutes that graduates of such a Centre would be employable.$^{86}$ By March of 1967, the Centre ${ }^{87}$ had opened under the Directorship of Otto Bier at the Escola Paulista de Medicina. ${ }^{88}$ In that same year, the Centre offered its first annual eightmonth course for postgraduates. Similar to the Ibadan course, the São Paulo programme was taught by the resident staff and a number of Western consultants. ${ }^{89}$

The research carried out at the Centre between 1967 and 1968 correlated well with the mechanistic focus of the contemporary American immunological tradition. The structure and function of antibodies was central to this research programme, whilst the effect of snake venom on the immune system received much interest. The only significant disease-centred research in progress at this time was a number of studies of the rare and little understood, fatal dermatological condition, pemphigus foliaceus.$^{90}$ Research in this early period was highly productive and led to many publications in international journals such as Immunology and the American Journal of Epidemiology. ${ }^{91}$

${ }^{83}$ Developments in malaria immunology, WHO Technical Report Series, No. 579, Geneva, WHO, 1975 , p. 4.

${ }^{84}$ Ibid.

${ }^{85}$ WHO Archive, Letter from H C Goodman to M G Candau (Director-General, WHO), 22 Oct. 1965, 15/286/4(C).

${ }^{86}$ WHO Archive, Letter from H C Goodman to Director-General, WHO, 22 Oct. 1965, I5/286/ 4(C).

${ }^{87}$ The São Paulo IRTC is referred to both as Center and Centre by different authors. For continuity I have used the English spelling Centre except where quoted.

${ }^{88}$ WHO Archive, Internal memo, Immunology, Geneva, to Regional Director, American Regional Office, 6 March 1967, I5/286/4(C).

${ }^{89}$ Consultants to the first course were $R$ Binagli (France), Byron Waksman (USA) and E A Kabat (USA). WHO Archive, 'WHO immunology research and training center: calendar of activities for the period 6-14 July 1967', I5/286/4(C).

\footnotetext{
${ }^{90}$ The cause and mechanism of fatality was unknown for pemphigus in this period. See William Boyd, Pathology: structure and function, London, Henry Kimpton, 1970, p. 1407.

${ }^{91}$ Examples of publications in this period include: O G Bier, M Siqueira, M B Esteves and $P$ M Freire, 'Quantitative relations in complement fixation', Am. J. Epidemiol., 1969, 89: 353-7; C Stiffel, A Rerini, H C Passos, O G Bier and G Biozzi, 'Rôle de la bourse de fabricius et du thymus dans la synthèse des anticorps opsonisants', Pathologie du Biologie, 1968, 16: 67-72; E H Beutener, L S Prigenzi, W Hale, C de A Leme and O G Bier, 'Immunofluorescent studies of autoantibodies to intercellular areas of epithelia in Brazilian Pemphigus foliaceus', Proc. Soc. Exp. Biol. Med., 1968, 127: 81-6; O G Bier, H C Passos and M Siquieria, 'Haemorrhagic reactions elicited at sites of passive cutaneous anaphylaxis by the intravenous injection of aggregated gamma globulin', Immunology, 1968, 14: 291-8.
} 
The immunology and parasitology sections of the WHO, however, did not find the Centre's research profile satisfactory. Within months of the Centre's first report in 1967, Dr N Ansari (Chief, Parasitic Disease, WHO) forwarded to Otto Bier a copy of P C C Garnham and John Humphrey's review of contemporary problems in leishmanial immunology. ${ }^{92}$ Bier's initial response was enthusiastic:

I read with great interest the condensed review of problems in Leishmaniasis related to immunity ... I am extremely pleased with the initiative taken by the parasitic diseases and the immunology units of WHO to put parasitologists and immunologists together in such an important field as the immunology of Leishmaniasis. Our Center will gladly accept to participate along the indicated lines in a programme of research to be co-ordinated by WHO in collaboration with laboratories in different parts of the world. ${ }^{93}$

Within a few months of this undertaking, however, the future of the Centre had come under immediate threat. South America had not been immune from the international student unrest so prominent in 1968. A student strike had led to the Dean of the host institution being deposed and a considerable re-distribution of power. As a result, "mere assistant professors [had been] made full professors and heads of departments". ${ }^{94}$ Otto Bier had been stripped of many of his responsibilities and both he and his staff had suffered numerous "humiliations". ${ }^{95}$ Consequently, all the Centre's staff had either left or were about to leave. Bier suggested, therefore, that the Centre move with him and a number of the staff to the Butantan Institute (a biological institute), or that it come under the control of Dr Victor Nussenzweig in the medical faculty of the University of São Paulo. ${ }^{96}$ Howard Goodman was quick to reply on behalf of the WHO: whilst they were keen not to rule out the "first rate" biological institute, they would prefer the Centre to be attached to a medical department. ${ }^{97}$ Records of the intermediate events have not survived but, by the end of 1968, the Assistant Director-General had prepared an agreement for the "Establishment of the WHO Immunology Research and Training Centre in São Paulo at the Butantan Institute". ${ }^{98}$ The move received the official blessing of the Secretary of State for Health ${ }^{99}$ and the agreement was signed on New Year's Eve, 1968. ${ }^{100}$ Due to the lack of documentary evidence, it is not clear why the Butantan Institute was chosen. It is likely, however, that the abilities Bier had shown as a scientist, manager and politician, made his retention as Director of the Centre preferable. Further, the relocation to a research institute protected the Centre from the consequences of future student protest.

\footnotetext{
${ }^{92}$ WHO Archive, Letter from Otto Bier to N Ansari, 1 April 1968, I5/286/4(C).

${ }_{93}^{93}$ Ibid.

${ }^{94}$ WHO Archive, 'A summarized report on the occurences at the Escola Paulista de Medicina and its consequences for WHO immunology research and training center, São Paulo, Brazil', 29 July 1968, I5/286/4(C).

${ }^{95}$ Ibid.

${ }^{96}$ Ibid.

${ }^{97}$ WHO Archive, Letter from H C Goodman to O G Bier, 7 Aug. 1968, I5/286/4(C).
}

${ }^{98}$ WHO Archive, Letter from A M M Payne to O G Bier, 2 Dec. 1968, I5/286/4(C).

${ }_{99}$ The letter urging the move to the Butantan Institute from the "Secretary of State for Health of São Paulo" is discussed in WHO Archive, Letter from Z Trnka to T DC, 12 Dec. 1968, I5/ 286/4(C).

${ }^{100}$ WHO Archive, Telegram O G Bier to H C Goodman, 31 Dec. 1968, I5/286/4(C). 


\section{The WHO and Immunology Research and Training, 1961-1974}

The change of location was accompanied by a change of title with the Centre being re-named the "Pan American Health Organization/World Health Organization Immunology Research and Training Center". This was intended to acknowledge the role the Pan American Health Organization (PAHO) had played in funding the Centre from early $1967 .{ }^{101}$ With the opening of the new Centre, and the associated upheavals, the commitment made by Bier to work on leishmanial immunology appears to have been forgotten. As a result, research deviated little from its original programme, with studies of the immunological effects of snake venom and immune mechanisms in pemphigus dominating. ${ }^{102}$

On 5 May 1971, Otto Bier's contract at the Butantan Institute expired. ${ }^{103}$ Bier refused re-appointment to the post of Director of the Centre on the grounds that he wished to return to bench research:

... what has really determined it is my desire to go back to do bench work while I still feel like being able to accomplish something in research. On the other hand working in the laboratory, I will give to the Center an important contribution orientating young members of the staff and helping to develop them into independent workers. ${ }^{104}$

Further, Bier freely admitted that he was "tired of having to deal with bureaucrats". ${ }^{105}$ Despite his resignation, his influence was to pervade the future of the laboratory: not least through his own selection of successor.

Upon announcing the cessation of his contract, Bier immediately suggested that Ivan Mota, a humoral immunologist working at the Centre, should be appointed to succeed him. In a letter to the WHO, Bier described Mota as a "shy and reserved person". ${ }^{106}$ Such a comment from the verbose and often bullish Bier could be considered as a criticism. However, Bier was quick to point out that Mota "gets along very well with the students and with the permanent staff besides being, as you know, a very serious and competent worker" ${ }^{107}$ Further, he hoped that releasing his salary would provide sufficient funds for the creation of a post of Associate Director. To this post he urged the appointment of the cellular immunologist, Dr Celso Bianco: "our best student in 1968". ${ }^{108}$ Bianco was at this time working with Victor Nussenzweig at New York University but was expected to return to Brazil by the end of 1971 .

By 25 May 1971, Ivan Mota had taken control of the Centre ${ }^{109}$ and Celso Bianco's return appeared to have been secured by the offer of the post of Head of the Division of Cellular Immunology at the Butantan Institute. ${ }^{110}$ With the arrival of a new

\footnotetext{
${ }^{101}$ Bier acknowledges the receipt of $\$ 670$ from the PAHO in WHO Archive, 'Report of activities in $1967,15 / 286 / 4(C)$.

${ }^{102}$ Four research projects are listed: response of patients with Brazilian Pemphigus foliaceus to treatment with azothioprine alone and in combination with triamcinolone; complement inactivation factor in Bothrops Venom; nephrotoxic activity of lambda 1 and lambda 2 guinea pig anti-kidney immunoglobulins; fixation of guinea pig lambda 1 and lambda 2 antibodies on guinea pig mast cells. WHO Archive, 'PAHO/ WHO Immunology Research and Training Centre at São Paulo, Brazil', I5/286/4(C).
}

${ }^{103}$ WHO Archive, Letter from O G Bier to $\mathrm{H}$ C Goodman 23 Nov. 1970, I5/286/4(C).

${ }^{104}$ WHO Archive, Letter from O G Bier to $\mathrm{H}$

C Goodman, 22 Jan. 1971, I5/286/4(C).

${ }^{105}$ Ibid.

${ }^{106}$ Ibid.

${ }^{107}$ Ibid.

${ }^{108}$ Ibid.

${ }^{109}$ WHO Archive, Letter from I Mota to G

Torrigiani (Immunology, WHO), 25 May 1971, I5/286/4(C)

${ }^{110}$ WHO Archive, Letter from I Mota to H C Goodman, 14 Jan. 1972, I5/286/4(C). 


\section{Richard Hankins}

Director, and the impending arrival of Bianco, the WHO were once again quick to attempt to introduce parasitology into the Centre's research. G Torrigiani of the WHO immunology section wrote to Bianco and Mota urging them to work on Chagas' disease:

We are now trying to encourage some research on Chagas' disease. I think that there is still a lot to be done in this field and I hope it will be easy to obtain support for such activity. Are you interested in studying the role of cell-mediated immunity in Chagas when you return to São Paulo? ... We would like very much to interest the São Paulo Centre in this activity and to this end I have already contacted Dr Ivan Mota. ${ }^{111}$

Mota replied to these promptings by informing Howard Goodman that with the arrival of Bianco he hoped "to develop with his help an entirely new line of research in the Center", ${ }^{112}$ but that he did not know of anyone interested in working on Chagas' disease. Bianco's response was more positive, suggesting that he might be prepared to do so. ${ }^{113}$ Consequently, Mota was again contacted and his collaboration sought. In response to the interest of Bianco in the subject, Mota replied that he would be "delighted" 114 to collaborate. However, Bianco chose instead to move to the Rockefeller Institute, New York, and as a result the WHO's hard-won concession was invalidated. ${ }^{115}$

The research interests of the Centre in 1972 remained very similar to those outlined in the first report. ${ }^{116}$ Despite repeated attempts, the WHO had been unable to amend this research profile in line with their own world health concerns. The position that Celso Bianco rejected was eventually accepted by W Dias da Silva, an immunologist specializing in aspects of anaphylaxis and formerly Professor of Immunology at the University of Belo Horizonte, Brazil.

In 1974, after almost a decade of WHO pressure on the Centre, Mota and Dias da Silva began research on parasite immunology after receiving a grant of US\$1,700 from the Brazilian National Research Council to study Chagas' disease. ${ }^{117}$ In the same year the Brazilian Society for Immunology, of which Otto Bier, Dias da Silva and Mota were all senior members, ${ }^{118}$ dedicated half of its second symposium to the "immunopathology of parasitic diseases with emphasis on Chagas' disease and schistosomiasis". ${ }^{119}$ By the end of 1974, staff at the Centre had prepared and presented papers on the cross reactivity between the response to Leptomonas pessoai

${ }^{111}$ WHO Archive, Letter from G Torrigiani to C Bianco, 23 Dec. 1971, I5/286/4(C).

${ }_{112}$ WHO Archive, Letter from I Mota to H C Goodman, 14 Jan. 1972, I5/286/4(C).

${ }^{113}$ WHO Archive, Letter from G Torrigiani to I Mota, 7 March 1972, I5/286/4(C).

${ }^{114}$ WHO Archive, Letter from I Mota to G Torrigiani, 24 April 1972, I5/286/4(C).

${ }^{115}$ WHO Archive, Letter from I Mota to G Torrigiani, 4 Oct. 1972, I5/286/4(C).

${ }^{116}$ WHO Archive, 'Draft brochure prepared for PAHO', I5/286/4(C). Research interests are listed as: The mechanism and production of homocytotropic antibodies in the guinea pig; the effect of splenectomy and thymectomy on reagin antibody production; the effect of Bordetella pertusis vaccine on cell-mediated immunity, factors present in $B$. pertussis cells responsible for their adjuvant effect; studies of the complement inactivating substances present in the venom of Bothrops jaracen.

${ }^{117}$ WHO Archive, Letter from I Mota to G Torrigiani, 21 Jan. 1974, I5/286/4(C).

${ }^{118}$ In 1972 Otto Bier was President, I Mota was Secretary and Dias da Silva was First Secretary of the Brazilian Society for Immunology. WHO Archive, Report of Activities 1972, I5/286/4(C).

${ }^{119}$ WHO Archive, Letter from I Mota to G Torrigiani, 21 Jan. 1974, I5/286/4(C). 
and Trypanosoma cruzi. Associated work at the Centre was in progress on the reticulo-endothelial system in $T$. cruzi infection in mice, and some collaborative work with a group working on "experimental Chagas" at the University of Belo Horizonte. ${ }^{120}$ By 1976, the Centre was offering a special course on the immunology of Chagas' disease. ${ }^{121}$

The research and training functions of the Centre continued until 1990 when the agreement between the WHO and the Butantan Institute was terminated. ${ }^{122}$ The activities of the Centre remained varied with studies of antibody production leading to numerous publications during the $1980 \mathrm{~s} .{ }^{123}$ The Centre was, however, greatly involved with parasite immunology research from the mid-1970s onwards, as reflected in a number of articles on trypanosomal immunology in international journals such as Clinical and Experimental Immunology and the Scandinavian Journal of Immunology. ${ }^{124}$ The highly collaborative nature of these papers shows that the Centre was influential in South America. The training function of the Laboratory both through the annual eight-month course, and the special course on Chagas' immunology further extended this influence, with students attending from across South America. Consequently, South American immunology was infused with the public health concerns of the WHO through the activities of the PAHO/WHO IRTC, São Paulo.

\section{WHO IRTC, Lausanne, Switzerland}

The WHO International Reference Centre for Immunoglobulins at the University of Lausanne was established in 1964. ${ }^{125}$ Following the death of its founder in 1966, it was decided to appoint a member of WHO staff to jointly head the Reference Centre and run an immunology research and training centre there. ${ }^{126}$ This decision was partly made on economic grounds - the Reference Centre was already furnished with advanced equipment and so it was possible to form an immunology research and training centre at almost no extra cost. Because of its European location and its combined Reference Centre/IRTC remit, it was proposed that the Lausanne IRTC would have a significantly different role to its peripheral counterparts:

the provision of reference services in research on immunoglobulins ...; exchange of scientific personnel with other Immunology Research and Training Centres and Immunology Reference Centres for the purposes of research and also refresher training;

\footnotetext{
${ }^{120}$ WHO Archive, 'Report of activities in 1974', I5/286/4(C).

${ }^{121}$ WHO Archive, Letter from $\mathrm{G}$ Torrigiani to I Mota, 1 Oct. 1976, I5/286/4(C).

${ }^{122}$ WHO Archive, Letter from T Phan Tan to Dr A Pelligrini, 25 April 1990, I5/286/4(C).

${ }^{123}$ For example, M F Maceda Soares, M S de Macedo and I Mota, 'Antigenic competition in IgE, IgG1 and IgG2 antibody production in the mouse', Int. Arch. Allergy Applied Immunol., 1985, 78: 499-51.

${ }_{124}^{12}$ For example, T L Kipnis, A U Krettli and W Dias da Silva, 'Transformations in trypomastigote forms of Trypanosoma cruzi into
}

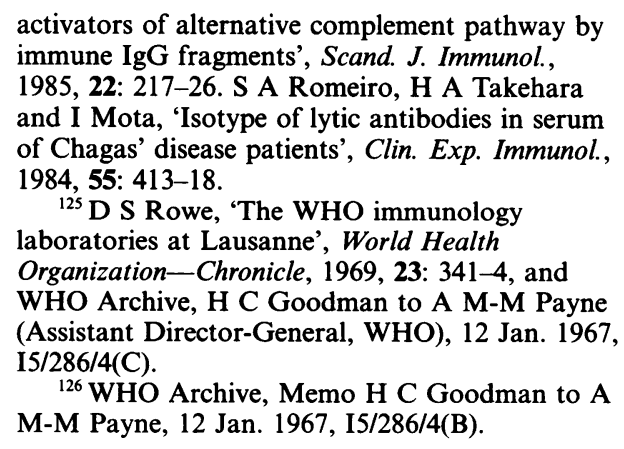
immune IgG fragments', Scand. J. Immunol., 1985, 22: 217-26. S A Romeiro, H A Takehara and I Mota, 'Isotype of lytic antibodies in serum of Chagas' disease patients', Clin. Exp. Immunol., 1984, 55: 413-18.

${ }_{125} \mathrm{D} S \mathrm{R}$ Rowe, 'The WHO immunology laboratories at Lausanne', World Health Organization-Chronicle, 1969, 23: 341-4, and WHO Archive, H C Goodman to A M-M Payne (Assistant Director-General, WHO), 12 Jan. 1967, I5/286/4(C).

${ }^{126}$ WHO Archive, Memo H C Goodman to A M-M Payne, 12 Jan. 1967, I5/286/4(B). 


\section{Richard Hankins}

the collection, exchange and distribution of immunological reagents which are rare or difficult to obtain or produce (antigens-antisera);

the organization of specialized courses in immunological techniques;

annual meetings of investigators and researchers on the use of human immunoglobulins (supported by an NIH grant);

and the handling of problems arising unexpectedly in the field of immunoglobulins (an example is the anti-D antibody in prevention of haemolytic disease of the newborn) ${ }^{127}$

The Lausanne IRTC was, therefore, to be concerned primarily with the supply, use and study of immunoglobulins. Its location limited the value of annual research courses such as those at São Paulo and Ibadan, as similar basic immunology courses were already available throughout Europe. The training function of the IRTC was instead to be met by the provision of highly specialized short courses and of longer term research facilities for semi-established scientists from developing countries. ${ }^{128}$

The post at Lausanne was created with David S Rowe, a humoral immunologist in Philip Gell's Birmingham University research group, already "lined up for the job". ${ }^{29}$ By May 1967, Rowe had accepted the post of "Chief Scientist (Immunologist)". ${ }^{130}$ Undaunted by his newly acquired administrative and managerial responsibilities, Rowe embarked on a dynamic programme of research. Between 1968 and the end of 1970 he published 34 articles in journals such as Nature, Bulletin of the World Health Organization, Clinical and Experimental Immunology, New England Journal of Medicine and Journal of Immunology. ${ }^{131}$ His research interests in this period were dominated by antibody studies with publications concerning $\operatorname{IgA},{ }^{132} \operatorname{IgD},{ }^{133} \mathrm{IgE}^{134} \mathrm{IgG}^{135}$ and $\mathrm{IgM}^{136}$ as well as a number of immunoglobulin surveys. ${ }^{137}$

Despite Rowe's heavy involvement in research, his administrative and training commitments appear to have been fulfilled. By October of 1969 the Centre had trained visitors from Uganda, Iran, Kenya, Czechoslovakia, Romania, Hungary and

\footnotetext{
${ }^{127}$ Ibid.

${ }^{128}$ For example, a short course on lymphoidal cell function was held in September 1969. D S Rowe, 'The WHO immunology laboratory', World Health Organization-Chronicle, 1969, 23:

${ }^{129}$ WHO Archive, Letter from D S Rowe to $\mathrm{H}$ C Goodman, 4 April 1967, I5/286/4(B).

${ }^{130}$ WHO Archive, Letter from H C Goodman to E A Kabat, 25 June 1967; Memo Chief, Immunology to Personnel, 6 May 1968, I5/286/

${ }^{131}$ Medline lists 39 articles by D S Rowe in this period.

${ }^{132}$ For example, R H Waldman, J P Mach, M $M$ Stella and D S Rowe, 'Secretory IgA in human serum', J. Immunol., 1970, 105: 43-7.

${ }^{133}$ For example, D S Rowe, S G Anderson and L Tackett, 'A research standard for human serum immunoglobulin D', Bull. World Health Organ., 1970, 43: 607-9.
} 342. 4(B).

\footnotetext{
${ }^{134}$ For example, D S Rowe and C B Wood, 'The measurement of serum immunoglobulin $\mathrm{E}$ levels in healthy adults and children with allergic asthma', Int. Arch. Allergy Applied Immunol., 1970, 39: 1-5.

${ }^{135}$ For example, D S Rowe, S G Anderson and B Grab, 'A research standard for human serum immunoglobulins IgG, IgA and IgM', Bull. World Health Organ., 1970, 42: 535-52.

${ }^{136}$ For example, J Bradley, D Normansell and D S Rowe, 'The metabolism of autologous IgM and 19s rheumatoid factor in rheumatoid arthritis', Clin. Exp. Immunol., 1969, 4: 537-53.

${ }^{137}$ For example, I A McGregor, D S Rowe, M E Wilson and W Z Bllewicz, 'Plasma immunoglobulin concentrations in an African (Gambian) community in relation to season, malaria and other infections and pregnancy', Clin. Exp. Immunol., 1970, 7: 51-74.
} 
Senegal. ${ }^{138}$ Regardless of the apparent success of these early years and the correlation between the research profile of the IRTC and the responsibilities of the Reference Centre, the WHO wanted a change of direction.

In March 1968, Howard Goodman wrote to John Humphrey at the National Institute for Medical Research, UK, to enquire whether a British group might be interested in working on the problems of immunity to leishmaniasis. Goodman went on to explain that if it were not possible to initiate sufficient research in Britain he hoped that a leishmania project could be developed at Lausanne. ${ }^{139}$ Humphrey's reply has not been retained. However, six months later David Rowe had secured approval for Wellcome Trust funding at the Lausanne Centre. ${ }^{140}$ The highly international nature of the laboratory justified funding for an institution so far outside the geographical remit of the Wellcome Trust:

the special position of ... [the] immunological research and training centre in Lausanne in relation to other parts of the world provided the trustees with sufficient justification to support fundamental laboratory work in a country other than Britain, and an exception was therefore made. ${ }^{141}$

The nature of this "special position" is not elaborated and it may refer either to the advanced facilities owned by the laboratory or the Centre's accessibility for training people from all over the world.

On New Year's Eve 1969, A M-M Payne, Assistant Director-General of the WHO, submitted an 'Application to the Wellcome Trust for Research on Immunological Mechanisms Operative in Tropical Disease' ${ }^{142}$ Five years' funding was requested for the formation of a parasite immunology research group at the Lausanne Centre. ${ }^{143}$ The application was the product of an official policy change on the part of the WHO. Following the success of the application, D S Rowe wrote to J Mauel, a viral and cellular immunologist at the Wistar Institute, Philadelphia, in an attempt to recruit him to the post of Wellcome Senior Research Fellow. In his letter, Rowe described the recent policy changes. It had now been "decided to broaden the interests of the WHO laboratory to essentially that of a laboratory of immunology related to the needs and interests of the WHO" ${ }^{144}$ In future, the Centre was to concentrate on "basic research" 145 and training in parasite immunology-especially leishmaniasis. The choice of this particular disease was based largely on the fact that a suitable model existed in the guinea pig and so the temperate location of the laboratory presented little inconvenience. ${ }^{146}$

\footnotetext{
${ }^{138}$ WHO Archive, Memo H C Goodman to Assistant Director-General and Director-General, 19 Sept. 1969, I5/286/4(B).

${ }^{139}$ WHO Archive, Letter from H C Goodman to J H Humphrey, 5 March 1968, I5/286/4(B).

${ }^{140}$ WHO Archive, Letter from P O Williams (Secretary, Wellcome Trust) to D S Rowe, 21 Oct. 1968, I5/286/4(B).

${ }^{141}$ Letter from B E C Hopwood (Director, Wellcome Trust) to D S Rowe, 17 May 1974, I5/ 286/4(B).
}

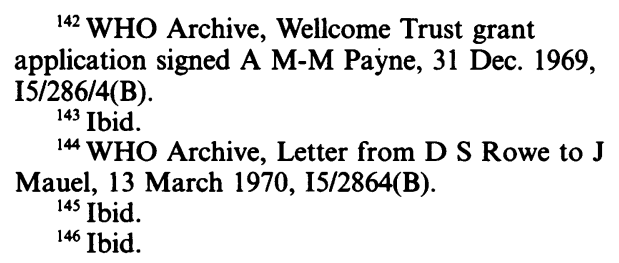




\section{Richard Hankins}

With the appointment of Mauel to the post, the laboratory gained an experienced immunologist. However, parasitological knowledge was lacking amongst the staff. To remedy this, an Iranian parasitologist, Dr R Behin, was appointed to "provide the technical background in parasitology". ${ }^{147}$ The addition of a further technician completed the "Leishmaniasis Group". ${ }^{148}$ Despite the founding of the new group, research at the Centre continued largely as it had since the 1960s. In the first three months of 1971 projects on the immune system in the respiratory tract and the immunoglobulins secreted by, and attached to, lymphocytes continued concurrently with the leishmania and immunoglobulin reference work. ${ }^{149}$

In February 1972, the Leishmania Group was expanded with the arrival of Dr Biroum-Noerjasin on a WHO fellowship during which he was to gain knowledge of cellular immunology. ${ }^{150}$ In the following year, the parasitological emphasis of the Centre was increased with the arrival of the veterinary parasitologist and immunologist Dr J J Doyle funded by the Wellcome Trust to research into the relationship between parasite antigens and immunity. ${ }^{151}$ Around the same time, Dr G I Pardoe, an immunochemist from the Birmingham group, began a research project at the Centre that included studies of the immunochemistry of parasite antigens. ${ }^{152}$ This coincided with the arrival of Dr A S Ghose, a WHO fellow from India who came for one year's research in leishmanial immunology, thus completing the expansion of the parasitology group. ${ }^{153}$ By 1974, of the seven researchers working at the Centre, only David Rowe retained an interest in immunoglobulin studies. Doctors Pardoe, Mauel, Behin, Biroum-Noerjasin, Doyle and Ghose were all involved in studies of parasite immunology. ${ }^{154}$ The parasitological emphasis was further secured in that year by the award of a grant from the agricultural division of the Rockefeller Foundation for work on antigenic variation in Trypanosoma brucei. ${ }^{155}$ The Wellcome Trust funding was also extended for a further year although this fell considerably short of the grant requested. ${ }^{156}$ This change of research interests was reflected in the teaching at the Centre, with the 1973 and 1974 courses being concerned with the "Immunology of Infectious Diseases". ${ }^{157}$ The 1973 course was attended by sixteen students and four observers representing a total of nineteen different countries.

Between 1967 and 1974 the WHO created, through deliberate policies, a parasite immunology centre at the University of Lausanne. Whilst the IRTC was based within the Immunoglobulin Reference Centre and originally followed a successful research programme associated with these reference functions, the development of cellular studies of leishmaniasis was heavily promoted. Influenced by this new

${ }^{147}$ Ibid.

${ }^{148}$ Ibid.

${ }^{149}$ WHO Archive, 'Quarterly field report', 20 April 1971, I5/286/4(B).

${ }^{150}$ WHO Archive, 'Quarterly field report', Jan. to March 1972, I5/286/4(B).

${ }^{151}$ WHO Archive, 'Quarterly field report', 1 April to 30 June 1973, I5/286/4(B).

${ }_{152}$ WHO Archive, 'Quarterly field report', 1 Jan. to 31 March 1973, I5/286/4(B).

${ }^{153}$ WHO Archive, 'Quarterly field report', 30 Sept. 1973, I5/286/4(B).
${ }^{154}$ WHO Archive, 'Quarterly field report', 5 Jan. 1974, I5/286/4(B).

${ }^{155}$ WHO Archive, Letter from J J McKelvey (Associate Director, Agricultural Sciences, Rockefeller Foundation) to D S Rowe, 15 March 1974, I5/286/4(B).

${ }^{156}$ WHO Archive, Letter from B E C Hopwood (Director, Wellcome Trust) to D S Rowe, 17 May 1974, I5/286/4(B).

${ }^{157}$ WHO Archive, 'Quarterly field report' 30 Sept. 1973 and 16 Oct. 1974, I5/286/4(B). 


\section{The WHO and Immunology Research and Training, 1961-1974}

research profile, the training function of the laboratory was changed, with visiting researchers from developing countries being involved in the parasitologically based research programme. The taught courses given by the Centre also changed significantly, providing training in the immunology of infectious diseases after 1973.

\section{Conclusions: The WHO and Immunology 1964 to 1974}

By 1973, WHO Immunology Research and Training Centres were operational in Nairobi, Singapore, New Delhi, Lausanne, Beirut, Mexico City, São Paulo, Ibadan, Rehovoth, Basel and Melbourne. ${ }^{158}$ This paper has provided a case study of only three of these Centres. In spite of existing differences in budget, structure and local traditions between the disparate Centres, the role of the WHO in the academic direction of all three institutions remained consistent. Further, the immunology of parasitic diseases can be shown to have been a considerable component of the research programme at Rehovoth, Nairobi, and New Delhi as well as at the three Centres examined.

The original structure outlined for the IRTCs in the report of the five Scientific Groups on Immunology in 1964 involved the transfer of both junior and senior Western staff to developing countries. ${ }^{159}$ Of the three laboratories examined here, only Ibadan relied upon the importation of such skilled scientists and was in a few years able to provide a "local" staff. Such an approach was inappropriate for the Swiss laboratory and unnecessary in Brazil where a small but advanced group of immunologists was already functioning. In fact, contrary to the assumed transfer of Western skills to the scientific periphery, the Lausanne laboratory relied on Iran for the provision of a competent parasitologist to facilitate their research programme. The assumption by the Scientific Group that the transplantation of Western scientists into Asia, Africa and South America would be required to stimulate the local formation of a professional discipline of immunology may have resulted from a failure to recognize that such a group existed in a limited form already. This misunderstanding was perhaps caused by the Western dominance of the committee that made the recommendations. The members of this group represented America, Australia, France and South Africa only. Interestingly, African and South American representatives were invited to attend another meeting in this series. ${ }^{160}$

The São Paulo Centre was staffed by South Americans and within a few years of its opening was able to invite numerous visiting consultants from elsewhere in the continent to teach and research at the Centre. ${ }^{161}$ This suggests the presence of a

\footnotetext{
${ }^{158}$ WHO Archive, Circular by H C Goodman to IRTCs, 28 March 1973, I5/286/4(A).

${ }^{159}$ Research in immunology, op. cit., note 25 above, p. 79 .

${ }^{160}$ Otto Bier (Brazil) and J C Edozien (Nigeria) were members of the Scientific Group on Immunochemistry. Research in immunology, op. cit., note 25 above, p. 79.

${ }^{161}$ The following were visiting Professors or Guest Lecturers at the São Paulo Centre in 1971:
}

Willy Becak (Butantan Institute, São Paulo), Otto G Bier (Department of Public Health, São Paulo), Guido Biozzi (Broussais Hospital, Paris), M Carnargo (Medical School, São Paulo), C Fava Neto (Medical School, São Paulo), R G Ferri (Medical School, São Paulo), S F Lara (Biochemistry, São Paulo), C Moreno (Chemistry and Pharmacy, University of Chile), S Leal Prado (Paulista School of Medicine, São Paulo), L S Prigenzi (Campinas State University, São Paulo), 


\section{Richard Hankins}

pre-existing immunological tradition within that continent. However, the research programme upon which the São Paulo Centre originally embarked was devoid of local concerns. Instead, the immunochemical and mechanistic interests of contemporary North American immunologists were allowed to dominate, possibly because South American immunologists had already been trained in North American institutes. It would appear that the eventual role of the WHO in Brazil was the reorientation of the embryonic local discipline to include studies of local infections such as Chagas' disease. The failure of the WHO to achieve this goal for almost a decade - even within its own Research and Training Centre-was a product both of Otto Bier's dominating personality, and of the fact that the WHO provided less than 20 per cent of the Centre's income. ${ }^{162}$

The success of the training programme of the Ibadan laboratory was recognized as limited despite the supervision of a number of doctoral students. The annual course was poorly attended and rarely attracted candidates from outside Nigeria. Consequently, as Houba himself admitted, the influence of the Centre on African science was distinctly limited. The research function of the laboratory was, however, considerably more successful. Whilst the prestigious publications outlined earlier were important in this, I would argue that the highly international nature of the collaborative projects undertaken was possibly even more important. These projects included such important figures as Tony Allison (NIMR, UK), John Soothill (Great Ormond Street Hospital, UK) and David Rowe (WHO IRTC, Lausanne) ${ }^{163}$ These contacts, combined with the numerous consultants such as A J S Davies (Chester Beatty Institute, UK) and C S Henney (Department of Medicine, Johns Hopkins School of Medicine, USA), placed the Ibadan Centre at the fulcrum of a worldwide network of immunology. Some of these actors were to play a significant role in the development of parasite immunology in other continents. For example, Tony Allison co-founded and edited the journal Parasite Immunology, whilst A J S Davies published many associated papers. Although the local success of this Centre may well have been limited, its international significance seems to have been great. Despite the achievements, frustration at the limits of the training programme of the Centre was a precipitating factor in the withdrawal of WHO staff in 1972, and the transfer of the laboratory to the control of the University of Ibadan.

Deliberate attempts were made by the WHO to further the international influence of the WHO IRTCs. On one occasion, Vashek Houba was funded to present a paper

W Dias da Silva (Medical School, Belo

Horizonte), M Siqueria (Paulista School of

Medicine, São Paulo), A Strauss (Medical School,

São Paulo), A Szenberg (Walter and Eliza Hall

Institute of Medical Research, Melbourne),

Professor N Vaz (Medical School, Niteroi Federal University, Rio de Janeiro).

${ }^{162}$ In 1967, the WHO provided the São Paulo Centre with US\$7,500 which is approximately 16.6 per cent of the total of US\$45,930 received in income that year. Other sources were the Pan
American Health Organization and the Escola Paulista. WHO Archive, 'WHO IRTC, São Paulo, Brazil: Report of activities in 1967 and plans for 1968', I5/286/4(C).

${ }^{163}$ Also R Hendrickse (University College Hospital, Ibadan, Nigeria), Professor Desmonde (Pasteur Institute, Dakar), I A McGregor (Medical Research Council Laboratories, Gambia) and G Binz (WHO Trypanosomiasis Project, Kenya). 


\section{The WHO and Immunology Research and Training, 1961-1974}

on malarial nephritis at a British Society for Immunology meeting in London. ${ }^{164} \mathrm{~A}$ couple of years later Howard Goodman arranged a session titled 'Practical and potential contributions of immunology to the problems of developing countries' at the Second International Congress of Immunology. ${ }^{165}$ The session was introduced and chaired by John Humphrey in Niels Jerne's absence, and consisted of papers by present and former Directors of four IRTCs as well as an introductory paper by Howard Goodman. ${ }^{166}$ The promotion of the WHO's immunological research interests, especially parasite immunology, was clearly the aim of this session. Goodman was convinced it had been successful in this respect, writing in the official report that he was "sure we made many recruits among the younger scientists who are interested in participating in this programme". ${ }^{167}$

Another mechanism through which the IRTCs exerted their influence was interaction with immunological societies. The Brazilian Society for Immunology was formed at the twenty-fourth meeting of the Brazilian Society for the Advancement of Sciences, following "a meeting of immunologists and people interested in immunology under the auspices of [the São Paulo] ... IRTC" ${ }^{168}$ The new organization was based at the São Paulo Centre and its committee was heavily dominated by present and former staff members, ${ }^{169}$ which testifies to the considerable influence of the WHO IRTC in Brazilian immunology. The numbers of South American visitors, coupled with the dominance of South American consultants to the annual course, demonstrate the degree to which the Brazilian Centre was an important locus in a South American network. The activities of the Brazilian Society were accordingly influenced by WHO concerns, with half of their second meeting being dedicated to parasitic disease. An immunology society was also founded within the Ibadan IRTC by Dr Salimonu, the centre's African technician. ${ }^{170}$ Appropriately, the inaugural lecture of this group was given by Howard Goodman who spoke on 'The role of WHO in immunology research and training. ${ }^{171}$

The funding and operation of the World Health Organization IRTCs can be considered to have been an attempt to promote interaction between the disciplines of parasitology and immunology. Although formed initially as centres for training

\footnotetext{
${ }^{164}$ Houba spoke at a BSI meeting in October 1970 at London. WHO Archive, 'Quarterly field report', July to Sept. 1970, I5/286/4(A).

${ }^{165}$ The Second International Congress on Immunology was held in Brighton, UK, 21-26 July, 1972. Letter from J H Humphrey to H C Goodman, 17 Jan. 1974, I5/86/13.

${ }^{166}$ Due to its late arrangement, the programme of this session was omitted from the programme of the conference. According to the provisional schedule, however, the session was to consist of the following papers: 'Introduction' by J H Humphrey; 'The role of the WHO' by $\mathrm{H} \mathrm{C}$ Goodman; 'The interaction of basic and applied research' by G J V Nossal; 'Some problems of India and her neighbours' by G P Talwar; 'Some problems of South America' by Otto Bier; 'Some problems in Africa' by B O Osunkoya; 'Closing
}

remarks' by J H Humphrey; WHO Archive, Letter from J H Humphrey to H C Goodman, 7 June 1974, I5/86/13.

${ }^{167}$ WHO Archive, 'Duty travel report: Second international congress of immunology at Brighton 21-26 July 1974', 8 Oct. 1974, I5/86/13.

${ }^{168}$ WHO Archive, 'Report of activities 1972', I5/286/4(C).

${ }^{169}$ The committee included O G Bier

(President), I Mota (Secretary), W Dias da Silva (First Secretary) and Maria Siqueiria (Second Treasurer). WHO Archive, 'Report of activities 1972', I5/286/4(C).

${ }^{170}$ WHO Archive, Letter from H C Goodman to Dr Salimonu, 30 April 1971, I5/286/4(A).

${ }^{171}$ Ibid. 


\section{Richard Hankins}

in general immunology, all three institutions in these case studies were rapidly transformed into parasite immunology research and training centres. This transformation can be seen to have been enforced despite considerable inertia from scientists loyal to more mainstream immunology research programmes. Whilst it is difficult to quantify the influence of the IRTCs, it is clear that the short-term consultancy system coupled with conference presentations, collaborative ventures and publication of material, contributed to the international dissemination of the research interests of the WHO. The direct effect of these activities on the disciplines of immunology and parasitology is unquantifiable. However, the involvement in this programme of highly regarded immunologists from across Europe and America infused immunology with a growing awareness of parasitological problems appropriate for investigation. A number of Western scientists who were involved with the Centres went on themselves to become influential parasite immunologists. The WHO IRTCs therefore form an important chapter in the history of the internationalization of endeavours to apply immunological knowledge and practices to parasitic diseases. Further, this programme was an important precursor to the much broader and more influential WHO tropical diseases research and training programme which was also headed by Howard Goodman. 